\title{
Effects of Carbohydrate and Artificial Substrate Integration on Growth Performance of Mudskipper (Pseudapocryptes elongatus)
}

\author{
Huynh Thanh Toi $^{1, *}{ }^{(D}$, Vu Hung Hai ${ }^{1}$, Nguyen Thi Hong Van ${ }^{1}$
}

${ }^{1}$ Can Tho University, College of Aquaculture \& Fisheries, Viet Nam

\section{How to cite}

Toi, H.T., Hai, V.H., Van, N.T.H. (2021). Effects of Carbohydrate and Artificial Substrate Integration on Growth Performance of Mudskipper (Pseudapocryptes elongatus). Turkish Journal of Fisheries and Aquatic Sciences, 21, 375-380. http://doi.org/10.4194/1303-2712-v21_8_02

\section{Article History}

Received 25 April 2020

Accepted 14 May 2021

First Online 19 May 2021

Corresponding Author

Tel.: +84936144272

E-mail: httoi@ctu.edu.vn

\section{Keywords}

Biofloc

Substrate

Mudskipper

\begin{abstract}
The carbon and artificial substrate integration was applied in mudskipper (Pseudapocryptes elongatus) culture to evaluate its effect on growth and enzyme activity. Wild mudskipper fries $(6.9-7.3 \mathrm{~cm} ; 3.88-4.12 \mathrm{~g})$ were obtained in the coastal area of the Mekong delta. Fish were reared in $1 \mathrm{~m}^{3}$ fiber glass tanks containing $600 \mathrm{~L}$ of $15 \%$ seawater for 60 days in outdoor conditions. Mud was added to the tank bottom around $15 \mathrm{~cm}$ to simulate the culture condition as would be found in an earthen pond. Molasses (38\% Carbon) was added daily to the culture water based on TAN level to balance $\mathrm{C} / \mathrm{N}$ to 10 . The results showed that the survival was in the range of $80.6-85 \%$, and no significance in term of survival was found when comparing treatments. The individual weight of fish was $11.93-14.11 \mathrm{~g} /$ ind in range, fish in the culture where carbon and both carbon and substrate addition had significantly better growth and productivity than fish in the culture where molasses and substrates were not applied. The results of this study demonstrate that the growth performance and production of mudskipper significantly increased when the biofloc and substrate integration was applied.
\end{abstract}

\section{Introduction}

Mudskipper (Pseudapocryptes elongatus, Cuvier, 1816), a brackish water fish species, is found in the canals or creeks of South East Asia (Bucholtz et al., 2009). This fish has a soft texture with a delicious and distinctive flavor (Fani et al., 2017), so the demand for this fish is always high, and it is one of the most economically valuable aquatic species to be cultured in salt water to replace shrimp. Mudskipper can be cultured with high density but aeration does not need to be applied to increase oxygen dissolved in water for fish (Minh et al., 2010), because they have the capacity to breathe air through their gills (Murdy, 1989). In addition, the culture water for growout pond does not require regular changing as for other fish species. Therefore, nitrogen waste accumulates with higher concentration by day during the culture period, and this may have a negative effect on the growth of fish. A new approach in aquaculture to reduce dissolved waste from the target animals is the biofloc technique which stimulates heterotrophic bacterial growth within the culture system. Heterotrophic bacteria obtain carbon and energy for growth from naturally occurring organic compounds (McGraw, 2012).

In addition, the effectiveness of submersed substrate in the aquaculture system has been reported to give more space for target animals and provides more 
room for periphyton to grow, and the resulting periphyton helps to control water quality (Schveitzer et al., 2013). The periphyton is also a natural food source for aquatic animals, as has been reported by better growth and the production of a target animal such as hybrid tilapia (Keshavanath, 2004) Macrobrachium rosenbergii (Chavez, 2015), Litopenaeus vannamei (Schveitzer et al., 2013; Dos Santos et al., 2019), Penaeus monodon (Kumar et al., 2019).

The Mudskipper is a herbivorous species, feeding mainly on pennate diatoms (Bucholtz et al., 2009). In an intensive culture system, mudskipper is acclimated to feed on floated commercial feed with small size from 0.6 $\mathrm{mm}$ to $2 \mathrm{~mm}$, but the effect of biofloc and substrate addition on the growth of mudskipper is still not studied, so that the aim of this study was to evaluate the effect of biofloc and substrate integration of the growth and enzyme activity of mudskipper.

\section{Material and Methods}

\section{Experimental Design}

Natural mudskipper $P$. elongatus fries $(6.90-7.30$ $\mathrm{cm}$; 3.88-4.12 g) was obtained from the Mekong delta coastal area. Fish were acclimated in four days, and after that the healthy fish were selected for study.

Fish were reared in 12 round fiberglass tanks $\left(1 \mathrm{~m}^{3} /\right.$ tank) containing $600 \mathrm{~L}$ of $15 \%$ o seawater at a stocking density of 240 ind. $/ \mathrm{m}^{2}$ for 60 days in outdoor conditions. Mud was added to the tank bottom at around $15 \mathrm{~cm}$ to simulate culture conditions as would be found in earthen ponds. The experiment consisted of 04 treatments, triplicate for each, as follows:

- Treatment $1(\mathrm{C}+\mathrm{S})$ : with carbohydrate and substrate addition

- Treatment 2 (C): with carbohydrate addition

- Treatment 3(S): with substrates additon

- Treatment 4 (Wo): without carbohydrate and substrate addition

Water exchange was performed when $\mathrm{NO}_{2}^{-}$in culture medium $\geq 2 \mathrm{mg} / \mathrm{L}$. An aeration was supported during the study.

\section{Carbon/Nitrogen (C/N) Manipulation}

Molasses (38\% carbon) was added to the mudskippers' culture medium to manipulate carbon/nitrogen $(\mathrm{C} / \mathrm{N})$ ratio to 10 . The amount of molasses added was based on a concentration of total ammonia nitrogen (TAN) in the culture medium.

\section{Feed and Feeding}

Commercial feed (De Hues, $40 \%$ protein) was provided at $15-20 \%$ of fish weight to the mudskipper; the total amount of feed for a day was divided and offered to the fish 04 times/day.

\section{Sample Collection and Analysis}

\section{Physio-chemical Parameters}

Temperature and $\mathrm{pH}$ were measured 2 times per day at 07:00 am and 14:00 pm. Nitrite $\left(\mathrm{NO}_{2}{ }^{-}\right)$and total ammonia nitrogen $\left(\mathrm{NH}_{3} / \mathrm{NH}_{4}{ }^{+}\right)$were tested in the morning over 3 days by Sera test-kit (Germany).

\section{Biological Parameters}

The weight and length of fish were determined for 30 fish on the first day and the end day of the experiment.

The final number of fish in each replication of each treatment was recorded at the end day of the study.

\section{Survival Rate and Growth Performance}

$$
\text { Survival }(\%)=100 x \frac{\text { number of individuals after experiment }}{\text { number of individuals before experiment }}
$$

Daily weight gain (g/day): DWG $=\frac{W 1-W 2}{t}$

Daily length gain $\left(\mathrm{cm} /\right.$ day): $\mathrm{DLG}=\frac{L 1-L 2}{t}$

Specific growth rate of weight (\%/day):

$$
\mathrm{SGR}_{\mathrm{w}}=\frac{100(\operatorname{LnW} 2-\operatorname{LnW} 1)}{t}
$$

Specific growth rate of length (\%/day):

$$
\mathrm{SGR}_{\mathrm{L}}=\frac{100(\operatorname{Ln} L 2-L n L 1)}{t}
$$

\section{Protease Assay}

The protease enzyme activity determined according to the methodology was described by Beg et al. (2002) with several modifications. To prepare the crude enzyme extract, $0.1 \mathrm{~g}$ of intestines were homogenized in $0.9 \mathrm{~mL}$ of PBS (Phosphate-buffered saline) buffer by a plastic pestle (25 s) in an Eppendorf tube and centrifuged at $10,000 \mathrm{rpm}$ for 10 minutes to obtain the intestinal enzyme solution at $4{ }^{\circ} \mathrm{C}$. The $100 \mu \mathrm{L}$ of supernatant was collected and then incubated with $100 \mu \mathrm{L}$ Casein $(1 \% \mathrm{w} / \mathrm{v})$ for 10 minutes at $37^{\circ} \mathrm{C}$, and then $500 \mu \mathrm{L}$ TCA $(5 \% \mathrm{v} / \mathrm{v})$ was added to stop the reaction. After 20 minutes, the mixture was centrifuged at 3000 rpm for 10 minutes to determine the protease activity according to the methodology as described by Lowry et al. (1951). A protease unit corresponds to the enzyme concentration required to release $1 \mu \mathrm{g}$ tyrosine $/ \mathrm{mL} / \mathrm{min}$ under standard conditions.

\section{Statistical Analysis}

The dataset of each treatment was calculated to get mean and standard deviation by Microsoft Excel software and statistically processed two-way ANOVA factor and the Tukey-HSD test by Statistica 7.0. 


\section{Results}

\section{Physio-chemical Parameters}

The temperature of culture medium varies in the range $27.6-30.5^{\circ} \mathrm{C}$ (Table 1 ). The concentration of TAN $\left(\mathrm{NH}_{4}{ }^{+} / \mathrm{NH}_{3}\right)$ in the culture medium is $1.52-1.59 \mathrm{mg} / \mathrm{L}$. Nitrite $\left(\mathrm{NO}_{2}{ }^{-}\right)$is $0.51-0.59 \mathrm{mg} / \mathrm{L}$.

\section{Growth Performance}

The growth results in length are shown in Table 2. The initial length of fish was $6.90-7.30 \mathrm{~cm} /$ fish. The final length of fish is shown in Table 2, the addition of molasses and substrate provided produced bigger fish, the growth of fish in length in $\mathrm{T} 1$ and $\mathrm{T} 2$ was no significantly better as compared to fish in T3 or T4. These results showed that both carbohydrate and substrate addition individually significantly improved on the growth in terms of length of fish, but there is no combined effect on the growth of fish (Table 3). The final weight of fish ranged between 12.26 and $14.51 \mathrm{~g}$, and there was significant difference between the treatments. The addition of molasses and substrate produced higher growth of fish, significantly better than the culture where molasses was not added and substrate was not provided. In addition, the daily weight gain and specific growth rate of fish in the culture where molasses was added and substrate provided was significantly better than fish in the culture where molasses was not added and substrates were not provided, but not significantly better than fish in a solely molasses-added culture. The addition of carbohydrate and substrate improved the higher survival rate of fish, but the increase was not significantly different $(P>0.05)$ when compared to the culture where carbohydrate and substrate were not applied. The fish yield ranged from $2.6-3 \mathrm{~kg} / \mathrm{m}^{3}$. The addition of molasses and substrate increased the production of fish as compared to that without molasses and substrate added. However, the significant increase of production in the molasses and substrate-added as compared to the control, but no significant difference was found when compared to the culture where solely molasses or substrate was added.

\section{Protease Activity}

Protease activity in fish increased in the culture where molasses was added only or a combination of molasses with substrate added, but protease activity was not increased when substrate was provided alone in the culture (Figure 1). In addition, the protease activity increased significantly in the culture where molasses was added.

\section{Discussion}

Mudskipper ( $P$. elongatus) is a herbivorous species, feeding mainly on pennate diatoms (Bucholtz et al., 2009). In an intensive culture, mudskippers are always

Table 1. The culture water parameters.

\begin{tabular}{lcccccc}
\hline \multirow{2}{*}{ Parameters } & \multicolumn{2}{c}{ Temperature $\left({ }^{\circ} \mathrm{C}\right)$} & \multicolumn{2}{c}{$\mathrm{pH}$} & \multirow{2}{*}{ TAN $(\mathrm{mg} / \mathrm{L})$} & $\mathrm{NO} 2^{-}(\mathrm{mg} / \mathrm{L})$ \\
\cline { 2 - 5 } & $7: 00$ & $14: 00$ & $7: 00$ & $14: 00$ & & \\
\hline NT1 (C+S) & $27.8 \pm 1.0$ & $30.5 \pm 1.4$ & $7.8 \pm 0.5$ & $7.7 \pm 0.4$ & $1.59 \pm 1.05$ & $0.59 \pm 0.53$ \\
NT2 (C) & $27.7 \pm 1.1$ & $30.2 \pm 1.3$ & $7.8 \pm 0.5$ & $7.7 \pm 0.4$ & $1.58 \pm 1.06$ & $0.57 \pm 0.55$ \\
NT3 (S) & $27.7 \pm 1.2$ & $30.4 \pm 1.4$ & $7.8 \pm 0.5$ & $7.6 \pm 0.5$ & $1.52 \pm 1.08$ & $0.51 \pm 0.46$ \\
NT4 (Wo) & $27.6 \pm 1.1$ & $30.1 \pm 1.4$ & $7.8 \pm 0.6$ & $7.6 \pm 0.5$ & $1.55 \pm 1.10$ & $0.52 \pm 0.53$ \\
\hline
\end{tabular}

Table 2. Growth performance in term of length of fish. Values are mean \pm standard deviation $(n=30)$. Different superscripts in the same row denote significant differences $(P<0.05)$.

\begin{tabular}{lcccc}
\hline Treatment & T1 (C+S) & T2 (C) & T3 (S) & T4 (Wo) \\
\hline$L_{\text {int }}(\mathrm{cm})$ & $6.90 \pm 0.80$ & $6.90 \pm 0.90$ & $7.20 \pm 1.60$ & $7.30 \pm 1.20$ \\
$\mathrm{~L}_{\text {final }}(\mathrm{cm})$ & $15.35 \pm 0.86^{\mathrm{a}}$ & $15.13 \pm 1.79^{\mathrm{a}}$ & $15.18 \pm 0.79^{\mathrm{a}}$ & $15.08 \pm 0.79^{\mathrm{a}}$ \\
$\mathrm{DLG}(\mathrm{cm} /$ day) & $0.14 \pm 0.01^{\mathrm{b}}$ & $0.13 \pm 0.01^{\mathrm{ab}}$ & $0.13 \pm 0.01^{\mathrm{ab}}$ & $0.13 \pm 0.01^{\mathrm{a}}$ \\
$\mathrm{W}_{\text {int }}(\mathrm{g})$ & $4.12 \pm 1.17^{\mathrm{a}}$ & $3.88 \pm 1.00^{\mathrm{a}}$ & $4.00 \pm 1.31^{\mathrm{a}}$ & $4.02 \pm 1.17^{\mathrm{a}}$ \\
$\mathrm{W}_{\text {final }}(\mathrm{g})$ & $14.51 \pm 2.06^{\mathrm{c}}$ & $13.58 \pm 2.92^{\mathrm{bc}}$ & $13.02 \pm 2.84^{\mathrm{ab}}$ & $12.26 \pm 2.25^{\mathrm{a}}$ \\
SGR(\%/day) & $2.09 \pm 0.14^{\mathrm{c}}$ & $2.07 \pm 0.24^{\mathrm{bc}}$ & $1.85 \pm 0.17^{\mathrm{a}}$ & $1.94 \pm 0.26^{\mathrm{ab}}$ \\
DWG(g/day) & $0.17 \pm 0.02^{\mathrm{c}}$ & $0.16 \pm 0.03^{\mathrm{bc}}$ & $0.13 \pm 0.02^{\mathrm{a}}$ & $0.15 \pm 0.03^{\mathrm{ab}}$ \\
Survival (\%) & $84.9 \pm 2.9^{\mathrm{a}}$ & $86.0 \pm 1.2^{\mathrm{a}}$ & $80.7 \pm 3.5^{\mathrm{a}}$ & $82.8 \pm 2.7^{\mathrm{a}}$ \\
Production (kg) & $3.03 \pm 0.19^{\mathrm{b}}$ & $2.96 \pm 0.03^{\mathrm{ab}}$ & $2.81 \pm 0.12^{\mathrm{ab}}$ & $2.57 \pm 0.25^{\mathrm{a}}$ \\
\hline
\end{tabular}

Table 3. $\mathrm{p}$-value of experimental factors on mudskipper performance. $* * *$ denotes $\mathrm{P}<0.001 ; * *$ : $\mathrm{P}<0.01$ and $*: \mathrm{P}<0.05)$.

\begin{tabular}{lccc}
\hline \multirow{2}{*}{$\mathrm{P}$-value } & \multicolumn{3}{c}{ Source of variation } \\
\cline { 2 - 4 } & Substrate $(\mathrm{S})$ & Carbohydrate $(\mathrm{C})$ & 0.8449 \\
\hline $\mathrm{L}_{\text {final }}$ & $0.0000^{* * * *}$ & $0.002^{* *}$ & $0.0208^{*}$ \\
$\mathrm{~W}_{\text {final }}$ & $0.0000^{* * * *}$ & $0.0000^{* * * *}$ & \\
\hline
\end{tabular}




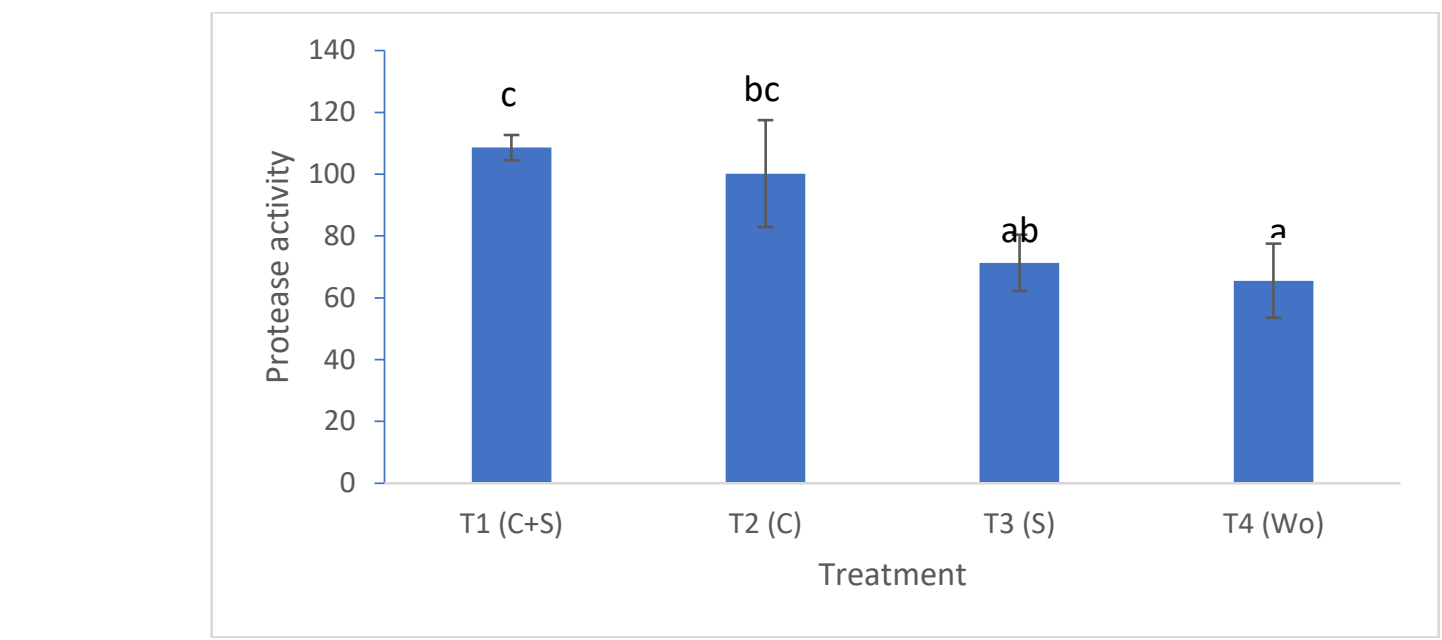

Figure 1. Protease activity in gastrodigestive tract of fish

acclimated to feed on floating commercial feed. However, the mudskipper has the capacity to breathe air through its gills (Murdy, 1989) and is able to tolerate high ammonium concentration in the culture medium, so that culture water is rarely exchanged in the intensive culture system. The biofloc technique has been demonstrated to improve water quality through stimulating bacterial growth (Hari et al., 2006). The biofloc may be used as food by the target animals (Avnimelech, 1999; Hari et al., 2004) thus resulting in savings on commercial food that has been demonstrated by previous studies on white-leg shrimp Litopenaeus vannamei (Burford et al., 2004), Nile tilapia Oreochromis niloticus (Avnimelech, 2011), and the black tiger shrimp Penaeus monodon (Anand et al., 2014; Kumar et al., 2019). Furthermore, the addition of carbon produced better growth of target animals, which has been demonstrated on white-leg shrimp post larvae, the biofloc producing better growth of shrimp because it stimulated shrimp to utilize more food (Kim et al., 2013). The improvement growth by biofloc has been reported on the common carp Cyprinus carpio L., where the better growth was obtained in the culture where biofloc was combined with $75 \%$ of commercial food as compared to the control provided with $100 \%$ commercial food (Najdegerami et al., 2015). The addition of submersed substrate in the culture medium helps increase natural periphyton productivity, which is the potential food source for target animals. This has been demonstrated on Litopenaeus vannamei (Schveitzer et al., 2013) Penaeus monodon (Kumar et al., 2019). The increased growth rate of fish in case of biofloc (bacterial forming) is generally linked to digestive enzyme activities (Long et al., 2015). The increase in digestive enzymes may lead to enhanced digestion and absorption of food, which in turn contributes to the improved survival and growth of fish. Biofloc are considered to be a source of exogenous extracellular enzymes (Verschuere et al., 1999; Maki et al., 2009). The increase of enzyme activities with the addition of specific bacterial strains in the culture medium has been demonstrated in marine larval shrimp Litopenaeus vannamei, Penaeus sp. (Rengpipat et al., 1998; Zhou et al., 2009; Nimrat et al., 2012) and Cyprinus carpio L. (Najdegerami et al., 2015). In the present study the protease activity increased in the culture where biofloc was applied, it resulted in better growth of fish as compared to the culture where substrate was individually provided or without carbon added.

In conclusion, the results of this study demonstrate that the growth performance and production of mudskipper significantly increased when the biofloc and substrate integration were applied to the culture. However, the study still remains to be validated in the earthen pond environment.

\section{Ethical Statement}

The data of this study is original work, and it has not been previously published in any journal.

Fish were used and cultured under condition with high applicable for Can Tho University guidlines which adapted from national guidelines on the protection and welfare of experimental animals in Viet Nam (Law on animal health; No. 79/2015/QH13). Before operating fish to get the gut samples for enzyme activity analysis, fish were starved for $24 \mathrm{~h}$, then sampled fish were immersed in ice-water slurry until unconscious.

\section{Funding Information}

The financial for this research has been supported by a Vietnamese Ministry of Education and Training (project number B2018-TCT-33).

\section{Author Contribution}

HTT and NTHV conceived of the presented idea, writing the research proposal and conducted a study. $\mathrm{VHH}$ was the one who was responsible for collecting fish gut samples and doing the emzyme analysis. At the end of study, all the author members dicussed on the results 
and interpret collected data for writing the manuscript. HTT was responsible for writing.

\section{Conflict of Interest}

On behalf of authorship, I declare that there was no conflicts of intest on this study.

\section{References}

Anand, P.S.S., Kohli, M.P.S., Kumar, S., Sundaray, J.K., Roy, S.D., Venkateshwarlu, G., \& Pailan, G.H. (2014). Effect of dietary supplementation of biofloc on growth performance and digestive enzyme activities in Penaeus monodon. Aquaculture, 418-419, 108-115. https://doi.org/10.1016/j.aquaculture.2013.09.051

Avnimelech, Y. (1999). Carbon/nitrogen ratio as a control element in aquaculture systems. Aquaculture, 176(3-4), 227-235.

https://doi.org/10.1016/S0044-8486(99)00085-X

Avnimelech, Y. (2011). Tilapia production using biofloc technology, saving water, waste recycling improves economics. Global Aquaculture Alliance. https://www.aquaculturealliance.org

Beg, Q.K., Saxena, R.K., \& Gupta, R. (2002). De-repression and subsequent induction of protease synthesis by Bacillus mojavensis under fed-batch operations. Process Biochemmistry, 37, 1103-1109. https://doi.org/10.1016/S0032-9592(01)00320-X

Bucholtz, R.H., Meilvang, A.S., Cedhagen, T. \& Macintosh, D.J. (2009). Biological observation on the mudskipper Pseudapocryptes elongatus in the Mekong Delta, Viet Nam. World Aquaculture Society, 40(6), 711-723. https://doi.org/10.1111/j.1749-7345.2009.00291.x

Burford, M.A., Thompson, P.J., McIntosh, R.P., Bauman, R.H., \& Pearson, D.C. (2004). The contribution of flocculated material to shrimp (Litopenaeus vannamei) nutrition in a high-intensity, zero-exchange system. Aquaculture, 232(1-4), 525-537.

https://doi.org/10.1016/S0044-8486(03)00541-6

Chavez, H.M. (2015). Effects of Artificial Substrate on Growth Performance, Survival and Production of Freshwater Prawn, Macrobrachium rosenbergii (de Man 1879) in Cages in Laguna de Bay, Philippines. Asian Fisheries Science, 28, 154-164.

https://doi.org/10.33997/j.afs.2015.28.4.002

Dos Santos, N.B.V., Furtado, P.S., Cesar, D.E., \& Junior, W.W. (2019). Assessment of the nitrification process in a culture of pacific white shrimp, using artificial substrate and bacterial inoculum in a biofloc technology system (BFT). Ciencia Rural, Santa Maria, 49(06), 1-10. https://doi.org/10.1590/0103-8478cr20180306

Fani, F., Maheno, W.S., \& Rani, Y. (2017). Maturation observation of gonad in mudskipper Pseudapocryptes elongatus from Kali Lamong river (Gresik, Indonesia). Russian Journal of Agricultural and Socio-Economic Sciences, 10(70), 306-311.

https://doi.org/10.18551/rjoas.2017-10.43

Hari, B., Kurup, M.B., Varghese, J.T., Schrama, J.W., \& Verdegem, M.C. (2004). Effects of carbohydrate addition on production in extensive shrimp culture systems. Aquaculture, 241(1-4), 179-194.

https://doi.org/10.1016/j.aquaculture.2004.07.002
Hari, B., Madhusoodana, K.B., Varghese, J.T., Schrama, J.W., \& Verdegem, M.C. (2006). The effect of carbohydrate addition on water quality and the nitrogen budget in extensive shrimp culture systems. Aquaculture, 252(24), 248-263.

https://doi.org/10.1016/j.aquaculture.2005.06.044

Keshavanath, P., Gangadhar, B., Ramesh, T., van Dam, A., Beveridge, M.C., \& Verdegem, M.C. (2004). Effects of bamboo substrate and supplemental feeding on growth and production of hybrid red tilapia fingerlings (Oreochromis mossambicus $\times$ Oreochromis niloticus). Aquaculture, 235(1-4), 303-314. https://doi.org/10.1016/j.aquaculture.2003.12.017

Kim, S.K., Pang, Z., Seo, H.C., Cho, Y.R., Samocha, T., \& Jang, I.K. (2013). Effect of bioflocs on growth and immune activity of Pacific white shrimp, Litopenaeus vannamei postlarvae. Aquaculture Research, 45(2), 362-371. https://doi.org/10.1111/are.12319

Kumar, S., Anand, P.S.S., De, D., Ghoshal, T.K., Alavandi, S.V., \& Vijayan, K.K. (2019). Integration of substrate in biofloc based system: Effects on growth performance, water quality and immune responses in black tiger shrimp, Penaeus monodon culture. Aquaculture Research, 50(10), 2986-2999. https://doi.org/10.1111/are.14256

Long, L., Yang, J., Li, Y., Guan, C., \& Wu, F. (2015). Effect of biofloc technology on growth, digestive enzyme activity, hematology, and immune response of genetically improved farmed tilapia (Oreochromis niloticus). Aquaculture, 448, 135-141.

https://doi.org/10.1016/j.aquaculture.2015.05.017

Lowry, O.H., Rosebrough, N.J., Farr, A.L., \& Randall, R.J. (1951). Protein measurement with the Folin phenol reagent. Journal of Biological Chemistry, 193, 265-275.

Maki, M., Leung, K.T., \& Qin, W. (2009). The prospects of cellulase-producing bacteria for the bioconversion of lignocellulosic biomass. International Journal of Biological Sciences, 5(5), 500-516. https://doi.org/10.7150/ijbs.5.500

McGraw, W.J. (2012). Utilization of heterotrophic and autotrophic bacteria in aquaculture. http://fau.digital.flvc.org.

Menaga, M., Felix, S., Charulatha, M., Gopalakannan, A., \& Panigrahi, A. (2019). Effect of in-situ and ex-situ biofloc on immune response of Genetically Improved Farmed Tilapia. Fish \& Shellfish Immunology, 92, 698-705. https://doi.org/10.1016/j.fsi.2019.06.031

Minh, T.H., Gallardo, W.G., \& Phuong, N.T. (2010). Fishery and Aquaculture of Juvenile Mudskipper Pseudapocryptes elongatus (Cuvier, 1816) in the Coastal Zone of Mekong Delta, Vietnam. Asian Fisheries Science, 23, 224-239. https://doi.org/10.33997/j.afs.2010.23.2.008

Murdy, E.O. (1989). A taxonomic revision and cladistic analysis of the oxudercine gobies (Gobiidae: Oxudercinae). Records of the Australian Museum, Supplement, 11, 193. https://doi.org/10.3853/j.0812-7387.11.1989.93

Najdegerami, E.H., Bakhshi, F., \& Lakani, F.B. (2015). Effects of biofloc on growth performance, digestive enzyme activities and liver histology of common carp (Cyprinus carpio L.) fingerlings in zero-water exchange system. Fish Physiology and Biochemistry, 42(2), 457-465. https://doi.org/10.1007/s10695-015-0151-9

Nimrat, S., Suksawat, S., Boonthai, T., \& Vuthiphandchai, V. (2012). Potential Bacillus probiotics enhance bacterial numbers, water quality and growth during early 
development of white shrimp (Litopenaeus vannamei). Veterinary Microbiology, 159(3-4): 443-450.

https://doi.org/10.1016/j.vetmic.2012.04.029

Rengpipat, S., Phianphak, W., Piyatiratitivorakul, S., \& Menasveta, P. (1998). Effects of a probiotic bacterium on black tiger shrimp Penaeus monodon survival and growth. Aquaculture, 167(3-4), 301-313. https://doi.org/10.1016/S0044-8486(98)00305-6

Schveitzer, R., Arantes, R., Baloi, M.F., Costódio, P.F.S., Arana, L.V., Seiffert, W.Q., \& Andreatta, E.R. (2013). Use of artificial substrates in the culture of Litopenaeus vannamei (Biofloc System) at different stocking densities: Effects on microbial activity, water quality and production rates. Aquacultural Engineering, 54, 93-103. https://doi.org/10.1016/j.aquaeng.2012.12.003

Verschuere, L., Rombaut, G., Huys, G., Dhont, J., Sorgeloos, P., \& Verstraete, W. (1999). Microbial control of the culture of Artemia juveniles through preemptive colonization by selected bacterial strains. Applied and Environmental Microbiology, 65, 2527-2533.

https://doi.org/10.1128/AEM.65.6.2527-2533.1999

Zhou, X.X., Wang, Y.B., \& Li, W.F. (2009). Effect of probiotic on larvae shrimp (Penaeus vannamei) based on water quality, survival rate and digestive enzyme activities. Aquaculture, 287(3-4): 349-353.

https://doi.org/10.1016/j.aquaculture.2008.10.046 